\title{
PEMANFAATAN PETILASAN MACAN PUTIH SEBAGAI SUMBER BELAJAR SEJARAH LOKAL BAGI GENERASI MUDA
}

\author{
Tian Fitriara Huda \\ Program Studi Pendidikan Sejarah Universitas PGRI Banyuwangi \\ email: tianfitriarahuda@gmail.com
}

\begin{abstract}
Abstrak
Penelitian ini bertujuan (1) mengetahui strategi yang dipergunakan dalam pemanfaatan Petilasan Macan Putih sebagai sumber belajar Sejarah Lokal bagi generasi muda, (2) mengetahui cara/metode pembelajaran yang diterapkan dalam memfungsikan Petilasan Macan Putih sebagai sumber belajar Sejarah Lokal. Penelitian ini merupakan penelitian kualitatif, dengan tahap-tahap yang dilakukan dalam penelitian adalah (1) penentuan rancangan penelitian, (2) penentuan lokasi penelitian, (3) penentuan informan, (4) pengumpulan data, (5) validitas data yang terdiri dari triangulasi data dan triangulasi metode, (6) analisis data. Hasil penelitian menunjukkan tiga sekolah yang berlokasi dekat dengan Petilasan, yaitu SMAN 1 Rogojampi, SMA PGRI Rogojampi dan SD Negeri 1 Macan Putih, memanfaatkan Petilasan Macan Putih sebagai sumber belajar Sejarah Lokal. Cara pemanfaatannya adalah dengan menggunakan strategi pembelajaran kontekstual (Contekstual Teaching Learning) dengan beberapa metode pembelajaran. Guru SMAN 1 Rogojampi, SMA PGRI Rogojampi menggunakan metode penjelajahan lingkungan sekitar dan metode studi sejarah murni. Sedangkan guru SD Negeri 1 Macan Putih menggunakan metode sosialisasi dalam pemanfaatan Petilasan ini sebagai sumber belajar.

Kata Kunci : Petilasan Macan Putih, Strategi Pembelajaran, Sumber belajar Sejarah
\end{abstract}

\begin{abstract}
This study aims to (1) determine the strategy that is used in the White Tiger Petilasan utilization as a source of learning local history to the younger generation, (2) know how learning methods are applied in the functioning Petilasan White Tiger as a source of learning local history. This study is a qualitative research, with research steps such as (1) the determination of the study design, (2) determining the location of the research, (3) determination of informants, (4) data collection, (5) the validity of the data that consists of triangulation data and triangulation methods, (6) the data analysis. The results showed that three schools located near Petilasan, SMAN 1 Rogojampi, SMA PGRI Rogojampi and SD Negeri 1 Macan Putih, Macan Putih Petilasan utilize as a source of learning local history. How utilization is to use contextual learning strategies (contextually Teaching Learning) with several learning methods. Teachers SMAN 1 Rogojampi, SMA PGRI Rogojampi using the browsing environment and purely historical study method. While teachers SD Negeri 1 Macan Putih using the method of socialization in Petilasan use this as a learning resource.
\end{abstract}

Keywords: Petilasan White Tiger, Learning Strategy, Learning Methods

\section{PENDAHULUAN}

Manusia membutuhkan pendidikan

dalam kehidupannya. Pendidikan merupakan usaha agar manusia dapat mengembangkan potensi dirinya melalui proses pembelajaran dan atau cara lain yang dikenal dan diakui oleh masyarakat. Aktivitas pelaksanaan pendidikan formal, tercermin salah satunya dalam proses pembelajaran. Proses pembelajaran sebagai aktivitas pendidikan dalam bentuk yang paling 
sederhana selalu melibatkan siswa dan guru. Dalam proses pembelajaran kedua belah pihak akan saling berkomunikasi dalam rangka mencapai tujuan pembelajaran.

Pendidikan merupakan usaha untuk mempersiapkan generasi bangsa menjadi manusia yang memiliki kemampuan dalam mengembangkan sumber daya yang potensial. Dalam usaha untuk mencapai hal tersebut, maka sangat diperlukan suatu usaha kreatif bagi penyelenggaraan pendidikan, terutama bagi generasi muda untuk dapat menjadi sosok generasi yang dapat membangun bangsa.

Generasi muda sebagai generasi penerus bangsa didorong untuk bertindak kepahlawanan dalam pembangunan atau mewarisi sifat-sifat kepahlawanan generasi sebelumnya. Nilai-nilai kepahlawanan harus ditanamkan pada generasi muda agar selalu cepat tanggap dan mampu mengatasi tantangan-tantangan pembangunan seperti keterbelakangan, frustasi mental, sifat pesimistis, dan lain-lain (Budiyasa, 2010: 111).

Salah satu mata pelajaran yang berperan vital dalam penanaman nilainilai karakter bagi generasi muda dalam upaya membangun ideologi dan rasa nasionalisme untuk pembangunan jati diri dan karakter bangsa adalah sejarah. Pendidikan sejarah ini dapat dibantu oleh peninggalan-peninggalan sejarah maupun bangunan memorial yang mengandung nilai-nilai tertentu sesuai dengan peristiwa sejarah yang melatarbelakanginya. Salah satunya adalah Petilasan yang berfungsi sebagai "memorial building" atau simbol ingatan terhadap suatu peristiwa sejarah.

Sebuah bangunan yang bernama Petilasan mampu menghadirkan kepada generasi berikutnya pengalaman para nenek moyang dan para pendahulunya. Dengan kata lain di sini kita dihadapkan dengan suatu reaktualisasi pengalaman kolektif suatu bangsa yang disebut dengan sejarah (Maryati, 2004: 15). Petilasan perjuangan sebagai sebuah memorial memiliki potensi sumber daya yang dapat dimanfaatkan oleh masyarakat, terutama generasi muda terkait dengan sumber belajar.

Salah satu Petilasan yang dapat dipergunakan sebagai sumber belajar Sejarah Lokal adalah Petilasan Macan Putih kawasan Macan Putih yang terletak di Kecamatan Kabat. Petilasan ini bisa menjadi salah satu tujuan untuk mengadakan pembelajaran di luar ruangan. Sejarah yang selama ini terkesan membosankan, melalui Petilasan ini yang dimanfaatkan sebagai sumber belajar Sejarah Lokal, dapat dijadikan sebagai salah satu alternatif untuk dapat merangsang minat belajar siswa dalam mata pelajaran sejarah. 
Berdasarkan latar belakang di atas, penelitian ini bertujuan untuk mengetahui strategi dalam pemanfaatan Petilasan Macan Putih sebagai sumber belajar Sejarah Lokal bagi generasi muda. Ini terkait pula dengan metode pembelajaran yang digunakan oleh guru/sekolah dalam menggunakan Petilasan sebagai sumber belajar Sejarah Lokal. Maka dari itu, penelitian pendidikan sejarah ini, dapat dijadikan sebagai suatu bahan untuk mengembangkan metode-metode belajar yang inovatif oleh sekolah, sehingga tidak hanya terbatas pada pembelajaran verbal saja. Hal ini terutama ditujukkan dalam mata pelajaran sejarah yang terkesan membosankan. Melalui penelitian ini, metode-metode belajar baru dapat digunakan sebagai reaktualisasi dalam penggunaan sumber belajar Sejarah Lokal daerah melaksanakan kegiatan pembelajaran secara aktif dan kreatif.

\section{METODE PENELITIAN}

Pada penelitian ini, penulis menggunakan metode penelitian kualitatif. Tahap-tahap dari penelitian kualitatif adalah sebagai berikut.

(1) Rancangan Penelitian

Penelitian ini adalah penelitian kualitatif yang bertujuan untuk mendeskripsikan dan menganalisis fenomena, peristiwa, aktivitas sosial, sikap, kepercayaan, persepsi, pemikiran orang secara individual maupun kelompok, beberapa deskripsi digunakan untuk menemukan prinsip-prinsip dan penjelasan yang mengarah pada penyimpulan.

(2) Penentuan Lokasi Penelitian Penelitian ini berlokasi di Macan Putih Kecamatan Kabat Kabupaten Banyuwangi.

(3) Teknik Penentuan Informan

Penentuan informan dalam penelitian ini menggunakan teknik purposive sampling. Informan di sini adalah guru sejarah SMAN 1 Rogojampi, SMA PGRI Rogojampi, Bapak Murtono dan guru kelas IV SD Negeri 1 Macan Putih, Ibu Warnasih.

(4) Teknik Pengumpulan Data

Pengumpulan data dalam penelitian ini menggunakan teknik observasi, wawancara dan studi dokumentasi.

(5) Validitas Data

Teknik cross cek data dalam penelitian ini menggunakan metode triangulasi yaitu teknik triangulasi data dan triangulasi metode.

(6) Teknik Analisis Data

Pada penelitian ini analisis data yang digunakan adalah model analisis interaktif.

\section{HASIL DAN PEMBAHASAN}

Keberadaan generasi muda di masyarakat tidak dapat diabaikan begitu saja karena kelangsungan masa depan 
masyarakat dan kebudayaan ditentukan oleh sikap dan perilaku kalangan generasi muda bersangkutan. Dengan demikian permasalahan di kalangan generasi muda perlu mendapat perhatian untuk meningkatan kualitas hidup generasi muda itu sendiri, masyarakat, bangsa dan negara. (Armini, 2005: 67). Berdasarkan hal tersebut, Petilasan Macan Putih memiliki peran yang vital bagi generasi muda Desa Macan Putih sebagai sumber belajar Sejarah Lokal, agar generasi muda Desa Macan Putih memiliki kepribadian dan dapat terus membawa Bangsa Indonesia khusunya Desa Macan Putih kearah yang lebih baik sesuai dengan cita-cita para pendahulunya.

Petilasan Macan Putih sebagai salah satu warisan sejarah sangat dibutuhkan disaat sekarang ini dalam rangka pencarian identitas diri dan menumbuhkan jati diri serta kepribadian yang positif dalam menghadapi tantangan zaman maupun dalam mengisi kemerdekaan ke depan. Hal ini sesuai dengan empat fungsi Petilasan yaitu sebagai sarana edukatif, rekreatif, inspiratif dan instruktif. Keempat fungsi tersebut terealisasikan dari beberapa cara dalam fungsi Petilasan Macan Putih sebagai sumber belajar Sejarah Lokal yang dijabarkan dalam dua sub pembahasan berikut.
Strategi yang Digunakan dalam Memanfaatkan Petilasan Macan Putih Sebagai Sumber Belajar Sejarah Lokal

Berbicara mengenai Petilasan Macan Putih sebagai sumber belajar, maka sasaran yang dituju yaitu sekolah (guru dan siswa). Berdasarkan hal tersebut, peneliti mengambil sampel (contoh) pemanfaatan Petilasan Macan Putih sebagai sumber belajar bagi generasi muda Desa Macan Putih, dari dua sekolah yang berlokasi tidak jauh dari Petilasan. Dua sekolah yang penulis jadikan sampel adalah SD Negeri 1 Macan Putih, SMAN 1 Rogojampi, dan SMA PGRI Rogojampi. Berdasarkan hasil observasi baik di SMAN 1 Rogojampi, SMA PGRI Rogojampi maupun di SD Negeri 1 Macan Putih, strategi pembelajaran yang dipergunakan oleh guru dalam pemanfaatan Petilasan Macan Putih sebagai sumber belajar Sejarah Lokal adalah strategi pembelajaran kontekstual (Contekstual Teaching Learning).

Pendekatan CTL merupakan konsep belajar yang membantu guru mengkaitkan antara materi yang diajarkan dengan situasi dunia nyata peserta didik dan mendorong siswa membuat hubungan antara pengetahuan yang dimilikinya dengan penerapannya dalam kehidupan mereka sebagai anggota masyarakat (Depdiknas, 2002: 1). Hal ini senada dengan yang diungkapkan oleh guru sejarah SMAN 1 
Rogojampi, SMA PGRI Rogojampi, Bapak Murtono (berdasarkan wawancara tanggal 16 November 2014) tentang strategi pembelajaran kontekstual dan penerapannya melalui penelitian langsung di lapangan. Setiap tahunnya guru sejarah kelas X SMAN 1 Rogojampi, SMA PGRI Rogojampi menugaskan siswa untuk mengadakan penelitian langsung ke lapangan dengan mengunjungi suatu situs sejarah atau meneliti suatu adat istiadat tertentu yang khas di lingkungan sekitar. Salah satunya adalah kunjungan siswa dalam tugas penelitian ke Petilasan Macan Putih. la juga menyatakan bahwa:

"Penelitian secara langsung
di lapangan bertujuan untuk
memberikan pemahaman secara
nyata kepada mereka dalam
melakukan penelitian ke lapangan
secara langsung. Walaupun hasil
karya anak-anak itu tidak
sempurna, akan tetapi setidaknya
format hasil penelitian mereka
sudah mengacu pada pedoman
penulisan skripsi atau karya
ilmiah"

Inilah salah satu kelebihan dari strategi pembelajaran kontekstual (CTL) yaitu siswa mendapatkan pengalaman secara langsung, sehingga ingatan siswa terhadap suatu materi menjadi lebih tajam. Maka dari itu, strategi ini dipergunakan oleh guru SMAN 1 Rogojampi, SMA PGRI Rogojampi dan SD Negeri 1 Macan Putih dalam memfungsikan Petilasan Macan Putih sebagai sumber belajar Sejarah Lokal.
Pendekatan pembelajaran sejarah melalui penggunaan Petilasan Macan Putih sebagai sumber belajar melalui CTL ini dapat dijalankan melalui enam metode yaitu (1) Metode sosialisasi informasi Sejarah Lokal dari guru kepada siswa tanpa mewajibkan siswa berada di lokasi; (2) Metode penjelajahan lingkungan sekitar; (3) Metode lawatan sejarah; (4) Metode wisata sejarah; (5) Metode studi sejarah murni; (6) Metode kemah budaya.

\section{Metode Pembelajaran yang Diterapkan dalam Memfungsikan Petilasan Macan Putih sebagai Sumber Belajar Sejarah Lokal}

Berdasarkan hasil observasi dan wawancara yang dilakukan di SMAN 1 Rogojampi, SMA PGRI Rogojampi, dan SD Negeri 1 Macan Putih, maka dapat dijabarkan metode pembelajaran yang digunakan dalam memanfaatkan Petilasan Macan Putih sebagai sumber belajar Sejarah Lokal. Pertama, hasil yang diperoleh di SMAN 1 Rogojampi, SMA PGRI Rogojampi, dapat diketahui bahwa, guru sejarah di sekolah ini menggunakan dua metode dalam pemanfaatan Petilasan Macan Putih sebagai sumber belajar Sejarah Lokal siswa-siswi kelas $X$ semester I (ganjil).

Mengambil acuan pada buku paket "Sejarah untuk SMA Kelas X karangan I Wayan Badrika (2006)" pada semester ganjil (I), siswa SMA kelas $X$ 
mendapatkan mata pelajaran sejarah yang di dalamnya terdapat materi "Prinsip-Prinsip Dasar Penelitian Sejarah" dengan Standar Kompetensi “Memahami Prinsip Dasar Ilmu Sejarah” dan Kompetensi Dasar “Menggunakan Prinsip-prinsip Dasar Penelitian Sejarah". Dalam SK dan KD terdapat beberapa indikator sebagai berikut:

1. Mendeskripsikan prinsip-prinsip dasar penelitian sejarah

2. Menerapkan prinsip kronologis dalam penelitian sejarah.

3. Mendeskripsikan peristiwa, peninggalan sejarah dan Petilasan peringatan bersejarah yang ada di sekitar.

Berdasarkan materi dan SK, KD beserta indikator yang ada, maka guru mata pelajaran sejarah di SMAN 1 Rogojampi dan SMA PGRI Rogojampi menggunakan Petilasan Macan Putih sebagai salah satu objek tujuan siswa dalam merealisasikan langkah-langkah penelitian sejarah sesuai dengan materi "Prinsip-Prinsip Dasar Penelitian Sejarah". Dalam materi ini, tidak seluruh siswa ditugaskan untuk mengadakan penelitian ke Petilasan Macan Putih. Ini disebabkan karena siswa dalam satu kelas dibagi menjadi beberapa kelompok kecil, dimana masing-masing kelompok mengadakan penelitian di tempat/dengan objek yang berbeda. Sebelumnya, guru memberikan materi terkait dengan prinsip-prinsip dasar penelitian sejarah. Setelah beberapa kali pertemuan/tatap muka, maka siswa kelas X.1 dibagi menjadi 4 (empat) kelompok kecil untuk diberikan tugas penelitian lapangan. Satu kelompok terdiri dari 6 sampai 7 orang.

Kemudian, metode pertama yang digunakan yaitu model penjelajahan lingkungan sekitar. Hal ini berkaitan dengan observasi mengenai apa saja yang terdapat di Petilasan Macan Putih, bagaimanakah situasi lingkungannya sehingga Petilasan Macan Putih dipilih sebagai tempat bagi basis gerakan perjuangan bawah tanah rakyat Bali.

Cara yang kedua yaitu melalui metode studi sejarah murni. Metode kedua ini berkaitan dengan metode pertama. Akan tetapi dalam metode kedua lebih ditekankan pada hasil akhir dari penelitian sejarah murninya. Dalam pelaksanaan pembelajaran materi "Prinsip-Prinsip Dasar Penelitian Sejarah" dengan menggunakan metode CTL ini, guru memberikan tugas akhir semester kepada siswa dalam bentuk portofolio atau makalah. Salah satu kelompok (berdasarkan kelompok yang telah dibentuk sebelumnya) diberikan tugas untuk meneliti mengenai sejarah Petilasan Macan Putih. Tugas ini seperti yang diterangkan oleh guru sejarah SMAN 1 Rogojampi, SMA PGRI Rogojampi, Bapak Murtono, merupakan tugas akhir semester yang memiliki waktu pengerjaan yang cukup lama, 
yaitu sekitar 2 bulan. Tugas ini merupakan tugas terstruktur yang diberikan pada akhir bulan Oktober dan disetorkan pada minggu kedua bulan Desember dalam bentuk portofolio/ makalah. Ini adalah output yang dihasilkan dalam metode studi sejarah murni yang dapat dijadikan sebagai nilai tugas ataupun ulangan harian dalam materi ini.

Menurut keterangan guru sejarah SMAN 1 Rogojampi, SMA PGRI Rogojampi, dengan menggunakan strategi pembelajaran ini dalam KBM, hasil evaluasi siswa dalam materi ini mengalami peningkatan. Ini dikarenakan siswa mengalami langsung atau dapat melakukan praktek langsung kelapangan terkait dengan materi prinsip-prinsip dasar penelitian sejarah. Maka dari itu, ingatan mereka tentang langkah-langkah penelitian sejarah tersebut lebih baik dari pada yang hanya mendengarkan penjelasan verbal dari guru. Hal senada juga diungkapkan oleh siswa SMAN 1 Rogojampi, SMA PGRI Rogojampi yang telah melakukan penelitian ke Petilasan Macan Putih. Diketahui bahwa siswa sangat antusias dengan diberikan tugas untuk mengadakan penelitian di Petilasan Macan Putih. Hal ini menjadikan mereka lebih memahami materi prinsip-prinsip penelitian sejarah dan menambah wawasan mereka tentang sejarah perang kemerdekaan di Bali, khususnya yang terjadi di lingkungan sekitarnya, yaitu di Desa Macan Putih.

Kemudian, hasil yang kedua yaitu pemanfaatan Petilasan Macan Putih sebagai sumber belajar bagi siswa di SD Negeri 1 Macan Putih. Setelah melakukan wawancara dengan guru kelas IV di SD Negeri 1 Macan Putih, yaitu Ibu Warnasih (43 thn), dapat diketahui bahwa, lain halnya seperti di SMA Negeri 1 Rogojampi, pembelajaran di Sekolah Dasar bersifat lebih sederhana bila dibandingkan dengan di SMA. Maka dari itu, pemanfaatan Petilasan Macan Putih sebagai sumber belajar siswa di SD Negeri 1 Macan Putih, hanya terbatas pada penyampaian materi terkait dengan contoh peninggalan sejarah. Materi ini terdapat pada pelajaran IPS (IImu Pengetahuan Sosial) kelas IV semester I. Metode ini termasuk dalam tipe penyajian informasi Sejarah Lokal (sosialisasi) dari pengajar kepada peserta didik tanpa mengharuskan peserta didik berada di lapangan. Pertama, guru mengacu pada materi kelas IV SD, yaitu materi mengenai "Menghargai Peninggalan Sejarah" semester I. Buku yang dipakai sebagai pedoman adalah Buku Ilmu Pengetahuan Sosial Kelas IV SD/ MI. Dalam materi “Menghargai Peninggalan Sejarah" pada sub. materi satu yaitu mengenai bentukbentuk peninggalan sejarah, terdapat 
beberapa tujuan pembelajaran yang harus dicapai oleh siswa yaitu:

a. Memahami pengertian peninggalan sejarah.

b. Menyebutkan contoh-contoh peninggalan sejarah yang ada di daerah masing-masing.

Berdasarkan materi dan tujuan pembelajaran inilah Petilasan Macan Putih dijadikan sebagai salah satu contoh peninggalan sejarah dalam bentuk bangunan yaitu Petilasan melalui metode ceramah/sosialisasi kepada siswa. Hasil evaluasi menunjukkan bahwa dengan digunakannya Petilasan Macan Putih sebagai contoh dalam materi pelajaran IPS, siswa SDN 1 Macan Putih menjadi tahu bahwa di lingkungan sekitarnya, terdapat suatu tempat bersejarah yang memiliki peran dalam perjuangan kemerdekaan dan revolusi fisik rakyat Bali. Inilah metode dan hasil yang diperoleh dari pemanfataan Petilasan Macan Putih sebagai sumber belajar Sejarah Lokal di SDN 1 Macan Putih.

\section{PENUTUP}

Petilasan Macan Putih memiliki fungsi sebagai sumber belajar khususnya bagi generasi muda Desa Macan Putih. Adapun cara pemanfaatan Petilasan Macan Putih sebagai sumber belajar oleh kalangan sekolah, dapat digambarkan dari hasil penelitian di SMAN 1 Rogojampi, SMA PGRI Rogojampi dan SDN 1 Macan Putih. Berdasarkan hasil observasi, guru SMAN 1 Rogojampi, SMA PGRI Rogojampi memanfaatkan Petilasan Macan Putih sebagai sumber belajar Sejarah Lokal terutama dalam materi Prinsip-Prinsip Dasar Penelitian Sejarah di kelas $X$ dengan menggunkan strategi pembelajaran kontekstual (CTL) dengan model penjelajahan lingkungan sekitar dan studi sejarah murni.

Kedua, pemanfaatan Petilasan Macan Putih sebagai sumber belajar siswa di SD Negeri 1 Macan Putih, hanya terbatas pada penyampaian materi terkait dengan contoh peninggalan sejarah (metode sosialisasi). Materi ini terdapat pada pelajaran IPS (Ilmu Pengetahuan Sosial) kelas IV (empat) SD semester I (ganjil).

Berdasarkan hasil temuan di lapangan, maka dapat disarankan kepada para guru atau pengajar lainnya, diharapkan Petilasan Macan Putih dapat difungsikan sebagai salah satu sumber belajar bagi siswa, dimana nantinya para pengajar khusunya bagi guru sejarah dapat mengembangkan media pembelajaran yang interaktif bagi para peserta didiknya, sehingga pelajaran sejarah tidak terkesan monoton dan lebih variatif.

\section{DAFTAR PUSTAKA}

Armini, I.G.A. 2005. Perubahan Pekerjaan Generasi Muda Pedesaan di Desa Nongan Kecamatan Rendang Kabupaten Karangasem "Jurnal Penelitian Sejarah dan Nilai Tradisional" 
(tidak diterbitkan). Departemen Kebudayaan dan Pariwisata: Balai Kajian Sejarah dan Nilai Tradisional Bali, NTB, NTT.

Badrika, I Wayan. 2006. Sejarah untuk SMA Kelas X. Erlangga: Jakarta.

Budiyasa, I Wayan Teguh.2010. Petilasan Perjuangan Rakyat Desa Macan Putih. Jurusan Pendidikan Sejarah Fakultas IImu Sosial Universitas Pendidikan Ganesha: Skripsi (Tidak Diterbitkan): Singaraja.

Depdiknas. 2002. Pendekatan Kontekstual (Contextual Teaching and Learning). Jakarta: Departemen Pendidikan Nasional. Maryati, Tuty; Sunada, Made. 2004. Pemanfaatan Media Petilasan dalam Pembelajaran Sejarah Nasional Indonesia II untuk Menumbuhkan Kesadaran Sejarah mahasiswa Jurusan Pendidikan Sejarah Semester III Tahun Ajaran 2004/2005. "Laporan Penelitian Tindakan Kelas" (tidak diterbitkan). FKIP Singaraja: Singaraja. 
Pemanfaatan Petilasan Macan Putih Sebagai Sumber Belajar ..., Tian Fitriara Huda, 53-62 